$\xi_{p}=$

\title{
Microbiological and physicochemical properties of commercial seal tampered refrigerated fruit juices
}

\author{
Olusola Adeoye Oluwole ${ }^{1 *}$, Oluwole Moses David ${ }^{1}$, Christopher Rotimi Falegan ${ }^{1}$, \\ Biodun Awojuyigbe $^{1}$, Olatunji Michael Olajide ${ }^{2}$ \\ ${ }^{1}$ Ekiti State University, Faculty of Science, Department of Microbiology, P.M.B. 5363, Ado-Ekiti, Ekiti State \\ ${ }^{2}$ Department of Food Science, Joseph Ayo Babalola University, Ikeji-Arakeji, Osun State, Nigeria \\ *Corresponding author E-mail: solaoluwole@ymail.com
}

\begin{abstract}
Microbial and physicochemical properties of seven branded, seal tampered refrigerated fruit juices were carried out in this study using standard methods. Coliform counts ranged from 2.079 to $3.093 \log _{10} \mathrm{cfu} / \mathrm{ml}$ over the storage period with pineapple juice and citrus juice having the highest and least coliform count respectively. Total bacteria count in the juice ranged from 7.009 to $8.243 \mathrm{log} 10 \mathrm{cfu} / \mathrm{ml}$. Citrus fruit juice however had the highest staphylococcal count while pineapple juice had the least (2.344 to $\left.3.881 \log _{10} \mathrm{cfu} / \mathrm{ml}\right)$. Also, osmophilic yeast count ranged from 2.017 to $3.903 \log _{10} \mathrm{cfu} / \mathrm{ml}$, having the highest load in orange fruit juice and lowest load in citrus fruit juice. The $\mathrm{pH}$ of the juice samples ranged from 2.9 to 4.2 during the period of refrigeration. Conductivity was highest in apple fruit juice and lowest in orange nectar pulp fruit juice. The total dissolved solids ranged from 0.29 to 1.95 over storage and was recorded highest in apple juice and lowest in orange nectar pulp fruit juice. Turbidity ranged from 5.8-200. These results indicate a reduction in the quality of fruit juices after 5 days of opening and thus reveals that both spoilage and pathogenic organisms could proliferate in juices despite refrigeration.
\end{abstract}

Keywords: Fruit Juices; Coliforms; Yeasts; Bacteria; Staphylococci.

\section{Introduction}

Over the years, humans and many animals have become dependent on fruits as a source of food (Lewis, 2002). Fruits can be classified as either juicy fruits such as lemon, orange, lime, tangerine and pomelo or pulpy fruits such as mango, pineapple, avocado, pear, guava, pawpaw, sour soup and banana (Abalaka, et al., 2013). Fruits are generally high in fiber, water, vitamin $C$ and sugars, which varies widely from traces in lime to $61 \%$ of the fresh weight of the date fruit (Hulme, 1971). However, due to the high perishability of fruits, it is essential to process it to a form that can be stored for longer period hence the idea of making fruit juices (Ndife et al., 2013).

Fruit juice is a non-fermented and non-sparkling fruit or vegetable beverage, obtained by the dilution in potable water of the juice, pulp or vegetable extract of the fruit of origin, with or without sugar (Piló et al., 2009). Juices can be obtained either by mechanical extraction processes or by reconstitution of concentrated fruit juice with clean water. Fruit juices are becoming a vital part of the modern diet in many communities Ghenghesh et al. (2005), accounting for more than $90 \%$ of the total fruit production in Nigeria (Odu and Adeniji, 2013). While homemade juices are usually consumed immediately, large scale commercially made juices are intended to stay for a period of time and are usually concentrated or preserved so as to stay consumable for a period of time. The low $\mathrm{pH}$ and high sugar content often is inhibitory to most organisms and more importantly pathogenic, toxigenic organisms including spore-formers like Clostridium botulinum (Olaniyi, 2013).
The microorganisms present in fruit juice often originate from the natural flora of the raw fruits used for the preparation and those introduced during the course of the processing (Splittstoesser et al., 1994; Yeh et al., 2004; Olaniyi, 2013). There have been several reports of incidences of food borne illnesses associated with the consumption of fruit juices (Sandeep et al., 2001; Ahmed et al., 2009; Sharma, 2013; Olorunjuwon et al., 2014) with the commonly implicated etiological agents being E. coli O157: H7 (Frank et al., 2004), and Salmonella (Cook et al. 1998; CDC, 1999).

Most of these outbreaks were however as a result of consumption of unpasteurized juices but an outbreak of botulism was recorded in pasteurized carrot juice consumption in USA in 2006 (CDC, 2006). During the heat treatment, pathogens and most non-sporeforming microorganisms are usually killed, but a heat process sufficient to destroy all the microbial spores will have a detrimental effect on the organoleptic quality of the product (Walls and Chuyata, 2000). In most cases fruit juices are prepared at home and are kept in the refrigerators or the industrial packed one are open, served and the remaining kept in the refrigerators. This study therefore aimed at determining the effect of refrigeration on microbial load and physicochemical properties of seal tampered commercially fruit juices.

\section{Materials and methods}

\subsection{Sample collection}


Seven brands of fruit juices were purchased from different supermarkets in Ado-Ekiti, Nigeria and the details on the juice pack were taken as shown in Table 1

Table 1: Brands of Juice Used for the Analysis with Their Manufacturing and Expiry Date

\begin{tabular}{|c|c|c|}
\hline Name of fruit juice & Designation & Shelf Life From Date Bought \\
\hline CHV apple juice & A & 8 months \\
\hline $\begin{array}{l}\text { CHV orange and } \\
\text { mango juice }\end{array}$ & B & 8 months \\
\hline DNS guava juice & $\mathrm{C}$ & 11 months \\
\hline $\begin{array}{l}\text { CHE orange nectar } \\
\text { with pulp }\end{array}$ & $\mathrm{D}$ & 7 months \\
\hline CHV pineapple & $\mathrm{E}$ & 11 months \\
\hline $\mathrm{CHV}$ orange juice & $\mathrm{F}$ & 7 months \\
\hline FVA citrus juice & $\mathrm{G}$ & 5 months \\
\hline
\end{tabular}

\subsection{Microbiological analysis}

The microbial quality of the juice samples were monitored for five days of storage in the refrigerator using the method described by Fawole and Oso (2001). Inoculum were plated on Nutrient agar (Oxoid), Eosin methylene blue (Oxoid), Malt-extract agar (Oxoid), and Mannitol salt agar (Oxoid) to determine the total heterotrophic bacteria, total coliform count, Osmophilic yeas count and staphylococcal load count respectively. The agar plates were incubated at $37^{\circ} \mathrm{C}$ for $24 \mathrm{~h}$ for bacteria and at $26^{\circ} \mathrm{C}$ for $72 \mathrm{hrs}$ for fungi.

\subsection{Physicochemical analysis}

The $\mathrm{pH}$, conductivity (EC), total dissolved solids (TDS), and the turbidity of the samples were evaluated every 24hours for a 5 day period (AOAC. 2005). The $\mathrm{pH}$ and TDS were measured using HANNA pH/EC/TDS meter H19813-0 while the turbidity was measured by turbidometer TBN 80120-1(Shanghai China Instrument and meter Limited).

\section{Results}

Table 2 shows the coliform load of stored commercial fruit juice samples under refrigeration conditions for 5 days. The coliform load value reduced in sample A from day 1 till day 3 but increased from day 4. Samples B and G coliform values increased from day 1 till day 2 but in sample B, it declined on day 3 till day 4 before increasing on day 5 while sample $G$ values were erratic, increasing and declining again while in samples B and G, it peaked on day 2 . Samples C and F's coliform loads was highest on days 3 and 4 respectively. The coliform count $\left(\log _{10} \mathrm{CFU} / \mathrm{mL}\right)$ ranged from 1.023 to 3.049 all across the samples (Table 2).

Table 2: Coliform Load $\left(\log _{10} \mathrm{CFU} / \mathrm{ml}\right)$ of Opened and Refrigerated Commercial Fruit Juice Samples

\begin{tabular}{llllll}
\hline Samples & \multicolumn{6}{l}{ Days of refrigeration after opening } \\
& 1 & 2 & 3 & 4 & 5 \\
\hline A & 3.000 & 2.944 & 2.778 & 2.857 & 2.881 \\
B & 2.079 & 3.049 & 2.903 & 2.778 & 2.944 \\
C & 2.833 & 2.806 & 2.903 & 2.881 & 2.857 \\
D & 3.033 & 2.857 & 2.944 & 2.924 & 2.903 \\
E & 3.093 & 2.778 & 2.903 & 2.778 & 2.903 \\
F & 2.857 & 2.505 & 2.000 & 2.903 & 2.857 \\
G & 2.602 & 3.017 & 2.778 & 2.944 & 2.748 \\
\hline
\end{tabular}

The osmophilic yeast count revealed an increase in count in sample A from day 1 till day 5 except on day 4 where there was a decline. Samples B and E increased in count on day 2 but decreased on day 3 only to increase on day 4 with subsequent decrease on day 5. Also, sample C's count was erratic decreasing on days 2 and 4 but increased on days 3 and 5 respectively. The count in samples D, F and G were similar in pattern, reducing in value from day 1 till day 3 while sample D's count increased from day 4 but samples $F$ and $G$ increased on day 5 of sampling (Table $3)$.

The staphylococcal count of the commercially sold fruit juice samples revealed that the count of sample A increased from day 1 to day 4 before declining on day 5. Sample D had high counts on days 1 and 2 but declined afterwards. This was also noticed in sample E. sample B and F had the highest counts on day 2 and the least counts on day 3 while sample $\mathrm{C}$ and $\mathrm{G}$ had their lowest counts on day 2 and highest counts on days 1 and 4 respectively (Table 4).

Table 3: Osmophilic Yeast Count $\left(\log _{10} \mathrm{CFU} / \mathrm{ml}\right)$ of Opened and Refrigerated Commercial Fruit Juice Samples

\begin{tabular}{llllll}
\multirow{2}{*}{ Sample } & \multicolumn{6}{l}{ Days of refrigeration after opening } \\
& 1 & 2 & 3 & 4 & 5 \\
\hline A & 2.017 & 3.009 & 3.107 & 3.017 & 3.903 \\
B & 2.944 & 3.000 & 2.93 & 2.944 & 2.881 \\
C & 2.982 & 2.064 & 2.857 & 2.832 & 2.925 \\
D & 3.049 & 3.017 & 2.748 & 2.806 & 2.881 \\
E & 3.000 & 3.924 & 2.602 & 2.903 & 2.778 \\
F & 3.064 & 3.017 & 2.924 & 2.778 & 2.857 \\
G & 3.000 & 2.945 & 2.881 & 2.806 & 2.881 \\
\hline
\end{tabular}

Table 4: Staphylococcal Load $\left(\log _{10} \mathrm{CFU} / \mathrm{ml}\right)$ of Opened and Refrigerated Commercial Fruit Juice Samples

\begin{tabular}{llllll}
\hline \multirow{5}{*}{ Sample } & \multicolumn{6}{l}{ Days of refrigeration after opening } & \\
& 1 & 2 & 3 & 4 & 5 \\
\hline A & 2.602 & 3.079 & 3.681 & 3.881 & 3.778 \\
B & 3.079 & 3.176 & 2.602 & 2.778 & 2.681 \\
C & 2.681 & 2.301 & 2.681 & 2.944 & 2.681 \\
D & 3.881 & 3.903 & 2.748 & 2.832 & 2.778 \\
E & 3.505 & 3.380 & 2.857 & 2.806 & 2.505 \\
F & 3.301 & 3.602 & 2.344 & 2.602 & 2.602 \\
G & 3.602 & 2.447 & 2.903 & 2.681 & 2.806 \\
\hline
\end{tabular}

The total bacterial counts of the samples showed a relatively high bacterial load. There was marked reduction in the population observed in the initial load of samples $\mathrm{A}$ and $\mathrm{C}$ on day 2 while other samples still maintained a high population with all but sample B increasing on day 2 . There was marked reduction on day 4 in sample $\mathrm{F}$ but it increased on day 5 while the lowest counts was observed on day 5 for sample B, day 4 for sample D, day 3 for samples E and G. Day 3 recorded the highest bacterial population in samples D and $G$ with others showing a relatively high population in comparison with other days (Table 5).

Table 5: Total Bacterial Count $\left(\log _{10} \mathrm{CFU} / \mathrm{ml}\right)$ of Opened and Refrigerated Commercial Fruit Juice Samples

\begin{tabular}{llllll}
\hline \multirow{2}{*}{ Sample } & \multicolumn{6}{l}{ Days of refrigeration after opening } \\
& 1 & 2 & 3 & 4 & 5 \\
\hline A & 8.017 & 7.199 & 7.217 & 8.103 & 8.000 \\
B & 8.033 & 8.009 & 8.049 & 8.029 & 7.029 \\
C & 8.049 & 7.025 & 8.207 & 7.017 & 8.103 \\
D & 8.009 & 8.209 & 7.201 & 7.037 & 7.964 \\
E & 8.093 & 8.093 & 7.207 & 7.944 & 8.182 \\
F & 8.000 & 8.049 & 8.199 & 6.964 & 8.093 \\
G & 8.079 & 8.243 & 7.009 & 8.049 & 8.017 \\
\hline
\end{tabular}

The physicochemical properties of the fruit juices were also monitored for the five days of refrigeration. The $\mathrm{pH}$ across the samples ranged from 3.1 to 4.1 . The $\mathrm{pH}$ generally dropped in the samples on day 2 except in sample $\mathrm{C}$ where there was an increase steadily till day 3 before it declined. Samples E and F also had a drop in $\mathrm{pH}$ till day 3 before increasing on day 4 . The $\mathrm{pH}$ of other samples A, B, D and G dropped on day 2 with intermittent increase and decrease in values till day 5. There was also intermittent fluctuations in the values of the other parameters (conductivity, Total dissolved solids and turbidity) with the patterns similar to what was observed in the $\mathrm{pH}$ readings over 5 days. The turbidity markedly reduced in all samples. 
Table 6: Physicochemical Analysis of Opened and Refrigerated Commercial Fruit Juice Samples

\begin{tabular}{|c|c|c|c|c|c|c|c|c|}
\hline \multirow{2}{*}{$\begin{array}{l}\text { Da } \\
\mathrm{y}\end{array}$} & \multirow{2}{*}{ Parameters } & \multicolumn{7}{|c|}{ Commercial fruit juice samples } \\
\hline & & A & $\mathrm{B}$ & $\mathrm{C}$ & $\mathrm{D}$ & E & $\mathrm{F}$ & $\mathrm{G}$ \\
\hline \multirow{5}{*}{1} & $\mathrm{pH}$ & 3.6 & 3.5 & 3.5 & 3.2 & 3.7 & 4.1 & 3.8 \\
\hline & $\begin{array}{l}\text { Conductivi } \\
\text { ty }\end{array}$ & 2.5 & 0.67 & 2.12 & 0.91 & 1.55 & 1.80 & 1.19 \\
\hline & $\begin{array}{l}\text { Total } \\
\text { dissolved } \\
\text { solids (g/l) }\end{array}$ & 1.86 & 0.43 & 1.56 & 0.65 & 1.22 & 1.32 & 0.59 \\
\hline & $\begin{array}{l}\text { Turbidity } \\
\text { NTU } \\
(1: 10)\end{array}$ & $\begin{array}{l}176 . \\
9\end{array}$ & 45.0 & $\begin{array}{l}102 . \\
0\end{array}$ & 55.0 & 19.6 & $\begin{array}{l}104 . \\
2\end{array}$ & $\begin{array}{l}194 . \\
1\end{array}$ \\
\hline & $\mathrm{pH}$ & 3.3 & 3.0 & 3.8 & 2.9 & 3.5 & 3.7 & 3.1 \\
\hline & $\begin{array}{l}\text { Conductivi } \\
\text { ty }\end{array}$ & 2.03 & 0.64 & 2.21 & 0.91 & 1.41 & 1.85 & 1.04 \\
\hline \multirow[t]{3}{*}{2} & $\begin{array}{l}\text { Total } \\
\text { dissolved } \\
\text { solids(g/l) }\end{array}$ & 1.48 & 0.42 & 1.63 & 0.65 & 1.02 & 1.35 & 0.74 \\
\hline & $\begin{array}{l}\text { Turbidity } \\
\text { NTU } \\
(1: 10)\end{array}$ & 90.6 & 13.0 & 57.6 & 30.0 & 12.4 & 98.3 & 44.1 \\
\hline & $\begin{array}{r}\mathrm{pHp} \\
\mathrm{pH}\end{array}$ & 3.4 & 3.2 & 4.2 & 2.8 & 3.3 & 3.2 & 3.5 \\
\hline \multirow[t]{5}{*}{3} & $\begin{array}{l}\text { Conductivi } \\
\text { ty }\end{array}$ & 2.24 & 0.77 & 0.40 & 1.09 & 1.49 & 2.01 & 1.20 \\
\hline & $\begin{array}{l}\text { Total } \\
\text { dissolved } \\
\text { solids(g/l) }\end{array}$ & 1.66 & 0.55 & 0.29 & 0.78 & 1.09 & 1.45 & 0.86 \\
\hline & $\begin{array}{l}\text { Turbidity } \\
\text { NTU } \\
(1: 10)\end{array}$ & $\begin{array}{l}120 . \\
1\end{array}$ & 5.8 & 200 & 40 & 22.2 & 85.2 & $\begin{array}{l}128 . \\
7\end{array}$ \\
\hline & $\mathrm{pH}$ & 4.1 & 3.8 & 3.0 & 3.7 & 4.1 & 3.5 & 3.8 \\
\hline & $\begin{array}{l}\text { Conductivi } \\
\text { ty }\end{array}$ & 2.04 & 1.45 & 0.61 & 1.35 & 1.84 & 1.43 & 2.20 \\
\hline \multirow[t]{4}{*}{4} & $\begin{array}{l}\text { Total } \\
\text { dissolved } \\
\text { solids(g/l) }\end{array}$ & 1.74 & 1.05 & 0.43 & 0.97 & 1.35 & 1.03 & 1.62 \\
\hline & $\begin{array}{l}\text { Turbidity } \\
\text { NTU } \\
(1: 10)\end{array}$ & $\begin{array}{l}140 . \\
0\end{array}$ & 12.3 & $\begin{array}{l}107 . \\
5\end{array}$ & 49.3 & 93.4 & 20.5 & 63.6 \\
\hline & $\mathrm{pH}$ & 3.7 & 3.6 & 3.1 & 3.5 & 3.7 & 3.6 & 3.5 \\
\hline & $\begin{array}{l}\text { Conductivi } \\
\text { ty }\end{array}$ & 2.60 & 1.48 & 0.62 & 1.30 & 1.30 & 1.47 & 2.09 \\
\hline \multirow[t]{2}{*}{5} & $\begin{array}{l}\text { Total } \\
\text { dissolved } \\
\text { solids(g/l) }\end{array}$ & 1.95 & $\begin{array}{l}1.06 \\
9\end{array}$ & $\begin{array}{l}0.43 \\
8\end{array}$ & $\begin{array}{l}0.93 \\
8\end{array}$ & 1.28 & 1.06 & 1.52 \\
\hline & $\begin{array}{l}\text { Turbidity } \\
\text { NTU } \\
(1: 10)\end{array}$ & 105 & 13.2 & $\begin{array}{l}129 . \\
0\end{array}$ & 73.7 & $\begin{array}{l}145 . \\
2\end{array}$ & 19.9 & $\begin{array}{l}157 . \\
7\end{array}$ \\
\hline
\end{tabular}

Keys: A-CHV Apple juice, B- CHV Pineapple juice, C-CHE Orange nectar pulp juice, D-DNS Guava juice, E-CHV Orange juice, F-FVA Citrus juice, G-CHV Mango and orange juice.

\section{Discussion}

In spite of the potential benefits offered by fruit juices, concerns over their safety and quality have been raised (Jackson et al., 2010). The processing units serve as potential source of bacterial and fungal contamination of fruit juices (Lateef and Yusuf, 2002). In this study we found out that coliform count of the samples analysed were relatively high ranging from $124 \mathrm{CFU} / \mathrm{ml}$ in Pineapple juice to $1240 \mathrm{CFU} / \mathrm{ml}$ in orange juice as shown in Table 2. Safe Food Consumption Standard prohibit coliforms in fruit juice (Andres et al., 2004), hence the juices were unsafe for consumption. Also, it is well above the regulatory specification of $<3 \mathrm{CFU} / \mathrm{ml}$ for total coliform counts in fruit juices (SON, 2008). The presence of coliform in fruit juice has been attributed to their being natural flora of fruits which may be introduced into the fruit juice if improperly processed (Frazier and Westhoff, 1998, Oranusi et al., 2012).

Table 3 showed that the osmophilic yeast count ranged from 60 $\mathrm{CFU} / \mathrm{ml}$ in citrus juice to $1280 \mathrm{CFU} / \mathrm{ml}$ in apple fruit juice. The Good Manufacturing Practices (GMP) standard limit for yeasts in fruit juices is $<10^{3} \mathrm{CFU} / \mathrm{ml}$ for unpasteurized fruit juices and $<10$ CFU/mL for pasteurized fruit juices (Braide et al., 2012), though the maximum acceptable level is $10^{6} \mathrm{CFU} / \mathrm{ml}$. It can then be deduced that the values recorded in this research exceeds that of the GMO standard as the juices were meant to have been pasteurized. Water and environment may play a major role in the fungi contamination of pineapple especially during washing of fruits (Abalaka et al., 2013). The presence of yeasts is expected due to its preference for sugar and low $\mathrm{pH}$, which highly favor yeast proliferation (Adams and Moss, 1995). High values observed in apple juices can reduce the shelf life the juice Sutherland et al. (1995) and may result in off flavors in the juice when consumed.

The results shown in Table 4 revealed the staphylococcal load of the fruit juices analysed. The load ranged from 120 to 8800 $\mathrm{cfu} / \mathrm{ml}$. Coagulase positive staphylococci may cause human diseases through the production of toxins. Effective levels of toxin formation however require a large number of microorganisms (approximately $10^{5}$ to $10^{6} \mathrm{CFU} / \mathrm{mL}$ of food) (IDF, 1994) hence, the risk of intoxication from consumption of these juices is highly unlikely. The presence of Staphylococcus spp. in all the juice samples can is an indication to contamination during handling which reflects poor personal and domestic hygiene as well as lack of knowledge of hygienic practices and safety of food products (Tambekar et al., 2009; Bello et al., 2013).

The total bacterial count in all juice samples were also considerably high, ranging from $9.2 \times 10^{6} \mathrm{cfu} / \mathrm{ml}$ to $17.5 \times 10^{7}$ $\mathrm{CFU} / \mathrm{ml}$ and this exceeded the maximum limit in the SON (2008) specification for commercial fruit juices $\left(<2.0 \times 10^{2} \mathrm{CFU} / 100 \mathrm{ml}\right)$ (Table 5). It was also discovered that the bacterial count peaked on the third day of storage in all the samples except sample D and G which peaked on the $2^{\text {nd }}$ day. Most fruit contains bacterial counts of $1 \times 10^{5} \mathrm{CFU} / \mathrm{cm}$ on their surface (Al-Jedah et al., 2002; Durgesh et al., 2008, Odu and Adeniji, 2013) hence; improper washing of fruits adds these bacteria to juices leading to contamination (Durgesh et al., 2008). The high count recorded is indicative of poor production and processing conditions Ezeama, (2007) and poses risk to consumers' health which should not be taken lightly (Dietary Guideline for Americans, 2005).

Table 6 shows the results of the physicochemical analysis of the fruit juice samples. The $\mathrm{pH}$ range from 2.9 to 4.2 indicating an acidic condition that promotes yeast growth and some bacteria species (Deak and Beuchat, 1993). It agrees with the $\mathrm{pH}$ range observed by Ndife et al. (2013) who recorded a pH range of 3.23 to 4.08. A report by Kareem and Adebowale, (2007) showed that the main acid in orange juice is citric acid. Food acids determine the prominent microflora in foods and to a large extent, the shelf stability of the juice (Ezeama, 2007). Acidic fruit juice is more yeasts and molds than mould (Jay, 2000). The turbidity ranged from 5.8 to 200 NTU during storage which is indicative of potential microbial activity. Statistical analysis of the results using univariate analysis of variance at $0.05 \%$ confidence limit showed significant difference between the samples.

\section{Conclusion}

The occurrence of higher than accepted limit of microbial contamination of fruit juice is alarming and reflects poor good manufacturing practices. Awareness program regarding the maintenance of hygiene and sanitation during processing should be effected. Quality control should be ensured also to forestall disease outbreak as a result of fruit juice consumption.

\section{References}

[1] Abalaka ME, Daniyan SY, Adeyemo SO, Abdulsalam R. (2013). Comparative Studies on Microbiological and Nutritional Qualities of Juice Produced From Pineapple. Journal of Biology and Today's World 2(1), 10-20. 
[2] Adams MR, Moss MO. (1995). Food Microbiology. Royal Society of Chemistry, Cambridge pp. 56 - 89, 130-131.

[3] Ahmed MSU, Nasreen T, Feroza B, Parveen S. (2009). Microbiological quality of local market vended freshly squeezed fruit juices in Dhaka city, Bangladesh. Bangladesh Journal of Scientific and Industrial Research, 44(4), 421-429.

[4] Al-Jedah JH, Robinson RK. (2002). Nutritional value and microbiological safety of fresh fruit juices sold through retail outlets in Qatar. Pakistan Journal of Nutrition, 1 (2), 79-81. http://dx.doi.org/10.3923/pjn.2002.79.81.

[5] Andres SC, Giannuzzi L, Zaritzky NE. (2004). Temperature effect on microbial growth in film packed apple cubes with preservative added orange juice. International Journal of Food Science and Technology, 39, 927-933. http://dx.doi.org/10.1111/j.13652621.2004.00870.x.

[6] Association of Analytical Chemists (AOAC). (2005). FDA Bacteriological Analytical Manual, 18th edition, Washington, DC.

[7] Bello OO, Bello TK, Bankole SA. (2013). Occurrence of antibiotic resistant Staphylococcus aureus in some street-vended foods in Ogun State, Nigeria. Journal of Advances in Biology, 1(1): 21-28.

[8] Braide W, Oranusi SU, Otali CC. (2012). Microbiological status of processed fruit juice sold in the commercial city of Onitsha. Scholarly Journal of Biological Science. 1(3), 23-30.

[9] Centre for Disease Control (CDC). (1999). Outbreak of Salmonella serotype Muenchen infection associated with unpasteurized orange juice in the United States and Canada, Journal of Morbidity and Mortality Weekly Report. 48(27), 582-585

[10] Centre for Disease Control (CDC). (2006). Botulism associated with commercial carrot juice-Georgia and Florida. Morbidity and Mortality Weekly Report 55, 1098-1099.

[11] Cook KA, Dobbs TE, Hlandy G, Wells JG, Barett TJ, Duhr ND. (1998). Outbreak of Salmonella serotype Hartford infections associated with unpasteurized orange juice. Journal of American Medical Association.

280:1540-9. http://dx.doi.org/10.1001/jama.280.17.1504.

[12] Deak T, Beuchat LR. (1993). Yeasts associated with fruit juice concentrates. J. Food Prot. 56, 777-782.

[13] Dietary Guidelines for Americans (2005). United States Department of Health and Human Services. United States Department of Agriculture Science. US Pp 425-430.

[14] Durgesh PM, Ranjana GK, Varsha KV. (2008). Microbiological analysis of street vended fruit juices from Mumbai city, India. Internet Journal of Food Safety. 10, 31-34.

[15] Ezeama CF. (2007). Food Microbiology: Fundamentals and Applications. Natural Prints Ltd. Lagos.

[16] Fawole MO, Oso BA. (2001). Laboratory Manual of Microbiology. Spectrum Books Limited, Ibadan. pp. 127

[17] Frank AA, Cooney RV, Henning SM, Custer LJ. (2004) Bioavailability and antioxidant effects of orange juice components in humans. Journal of Agriculture and Food Chemistry, 53(13) 5170-8. http://dx.doi.org/10.1021/jf050054y.

[18] Frazier WC, Westhoff DC. (1988). Food Microbiology. $4^{\text {th }}$ Edition, McGraw Hill, New Delhi pp. 83-98, 196-215

[19] Ghenghesh KS, Belhaj K, El-Amin WB, Nefathi E, Zalmum A (2005). Microbiological quality of fruit juices sold in TripoliLibya. Food Control Journal, 16: 855-858. http://dx.doi.org/10.1016/j.foodcont.2004.06.028.

[20] Hulme AC. (1971). Biochemistry of fruits and their products Mangoes: Dehydrated fruits. Vol.II. Academic Press, London and New York Pp.233-234,623-648

[21] International Dairy Federation (IDF). (1994). Recommendations for the hygiene manufacturer of milk and milk based products, appendix A. In: Spoilage and Pathogenic Bacteria in Milk Based Products, Belgium: International Dairy Federation. pp 28-30.

[22] Jackson C, Ibezim E, Akeem A, Udofia M, Odo H (2010) Determination of bioload of commercially available brands of fruit juices in Uyo, Nigeria. Research in Pharmacy and Biotechnology. 2(4), 51-53.

[23] Jay MJ. (2000). Modern Food Microbiology. (6 ${ }^{\text {th }}$ ed.) Aspen Publishers Inc., Gaithersburg, Maryland. http://dx.doi.org/10.1007/978-1-4615-4427-2.

[24] Kareem SO, Adebowale AA. (2007). Clarification of orange juice by crude fungal pectinase from citrus peel. Nigerian Food Journal 25(1), 130-137. http://dx.doi.org/10.4314/nifoj.v25i1.33661.

[25] Lateef A, Yusuf WA. (2002). Evaluation of the Mirobiological safety of some NAFDAC approved pure water in some Nigerian cities. Journal of Nigerian Society for Experimental Biology. 2:199 211
[26] Lewis RA. (2002). CRC Dictionary of Agricultural Sciences. CRC Press.

[27] Ndife J, Awogbenja D, Zakari U. (2013). Comparative evaluation of the nutritional and sensory quality of different brands of orangejuice in Nigerian market. African Journal of Food Science. 7(12): 479-484. http://dx.doi.org/10.5897/AJFS2013.1060.

[28] Odu NN, Adeniji AO. (2013). Microbiological Analysis of some Packaged Fruit Juices sold in Port Harcourt Metropolis, Nigeria. Nat. Sci. 11(4):30-40.

[29] Olaniyi OO. (2013). Microbiological quality assessment of some National Agency for Food and Drug Administration and Control (NAFDAC) approved fruit juices sold in Ilorin metropolis African Journal of Food science, 7(8): 222-226.

[30] Olorunjuwon BO, Temitope BK, Muibat FO, Afolabi O. (2014). Microbiological quality of some locally produced fruit juices in Ogun state, South Western Nigeria. Journal of Microbiology Research, 2(1), 1-8

[31] Oranusi US, Braide W, Nezianya HO. (2012). Microbiological and chemical quality assessment of some commercially packed fruit juices sold in Nigeria. Greener Journal of Biological Sciences, 2(1):1-6.

[32] Piló FB, Pereira NO, Freitas D, Miranda ND, Carmo SD, Gomes CO, Nardi MD, Rosa CA. (2009). Microbiological testing and physical and chemical analysis of reconstituted fruit juices and coconut water. Journal of Alimentaria Nutria, 20(4): 523-532.

[33] Sandeep M, Diwakar A, Abhitjit G. (2001). Microbiological analysis of street vended fresh squeezed carrot and kinnowmandarian juices in Patiala city, India. Internet Journal of Food Safety, 3, 1-3.

[34] Sharma PU. (2013). Bacteriological analysis of street vended fruit juices in Vidharbha. International Journal of Current Microbiology and Applied Sciences, 2(5), 178-183

[35] Standards Organization of Nigeria (SON) (2008). Standard for Fruit Juice. Standards Organization of Nigeria. ICS 67.160.20. NIS 235

[36] Splittstoesser DF, Churey JJ, Lee CY (1994). Growth characteristics of aciduric spore-forming bacilli isolated from fruit juices. Journal of Food Protection. 57: 1080-1083.

[37] Sutherland JP, Bayliss AJ, Braxton DS. (1995). Predictive modeling of growth of Escherichia coli O157:H7: The effects of temperature, $\mathrm{pH}$ and sodium nitrite. International Journal of Food Microbiology 25: 29-49. http://dx.doi.org/10.1016/01681605(94)00082-H.

[38] Tambekar DH, Jaiswal VJ, Dhanorkar DV, Gulhane PB, Dudhane MN. (2009). Microbial quality and safety of street vended fruit juices: A case study of Amravati city. Internet Journal of Food Safety, 10: 72-76.

[39] Walls I, Chuyate R. (2000). Isolation of Alicyclobacillus acidoterrstris from fruits juices. Journal of Association of Analytical Chemists. 83: 1115-1120.

[40] Yeh JY, Ellis H, Chen J. (2004). Influence of calcium lactate on the fate of spoilage and pathogenic microorganisms in orange juice. $\mathrm{J}$. Food Prot. 67, 1429-1433. 